\title{
The use of in-situ produced cosmogenic radionuclides in glaciology and glacial geomorphology
}

\author{
Derek Fabel, Jon Harbor \\ Earth and Atmospheric Sciences, Purdue University, West Lafayette, IN 47907-1397, U.S.A.
}

\begin{abstract}
The usefulness of in-situ produced cosmogenic radionuclides in constraining glacial chronologies through exposure-age dating has been demonstrated in numerous studies. However, an understanding of cosmogenic radionuclide techniques and their uncertainties opens up a wide range of other potential applications in glaciology and glacial geomorphology. Recently developed applications include: estimation of spatial and temporal variations in the depth of glacial erosion from cosmogenic radionuclide inheritance, which provides important constraints on process-based erosion models; and burial dating, which can provide chronological control for glacial advances and the onset of till deposition. An interesting new application, currently at the level of theoretical model development, concerns the unraveling of complex exposure and burial histories. Overall, in-situ produced cosmogenic radionuclide techniques provide a means with which to constrain a wide range of ice-sheet and glacial models over time-scales of a thousand to a few million years.
\end{abstract}

\section{INTRODUCTION}

Cosmogenic nuclide techniques are revolutionizing the study of geomorphic processes and landscape history. The ability to date rock surfaces and sediments, over a wide range of time-scales, allows us to address many problems that were previously unsolvable (reviewed in Nishiizumi and others, 1993; Cerling and Craig, 1994). For example, in reconstructing past glacial events, attempts to establish chronologies have often been frustrated by the lack of suitable organic material for radiocarbon dating. All too frequently, only undatable rocks and sediments were available for analysis. Now, with cosmogenic nuclide techniques, the rocks and sediments can be dated. Determination of exposure histories of features such as moraine boulders, glacial pavements and trimlines, lava flows, shore platforms, alluvial fans, landslides, cliff surfaces, and meteorite impact deposits has been the major application (e.g. Craig and Poreda, 1986; Kurz, 1986; Phillips and others, 1986, 1990, 1991, 1996a, b, 1997; Klein and others, 1988; Cerling, 1990; Nishiizumi and others, 1991a, b, 1993; Gosse and others, 1995a, b; Brook and others, 1996b; Stone and others, 1998b). However, cosmogenic nuclide techniques can also be applied to determine the erosion rates of surfaces and to date burial events (e.g. Nishiizumi and others, 1993; Granger and others, 1996, 1997; Davis and others, 1999).

This paper provides an overview of cosmogenic radionuclide techniques and the underlying assumptions, uncertainties and sample requirements, as well as theoretical considerations that illustrate potential uses of the techniques in glaciology and glacial geomorphology.

\section{IN-SITU COSMOGENIC RADIONUGLIDES}

The Earth is continually bombarded by cosmic rays which are largely attenuated by the atmosphere. Those cosmic rays that do reach the Earth's surface interact with atomic nuclei in minerals near the Earth's surface to produce in-situ cosmogenic nuclides, such as stable ${ }^{3} \mathrm{He}$ and ${ }^{21} \mathrm{Ne}$ and radioactive ${ }^{10} \mathrm{Be},{ }^{14} \mathrm{C},{ }^{26} \mathrm{Al},{ }^{36} \mathrm{Cl}$ (Cerling and Craig, 1994). Recent advances in nuclear instrumentation allow measurement of very low concentrations of these rare nuclides. Three cosmogenic radionuclides are commonly used in applications of the cosmogenic nuclide technique to problems in glaciology and glacial geomorphology: ${ }^{10} \mathrm{Be}$ and ${ }^{26} \mathrm{Al}$, which are cre-

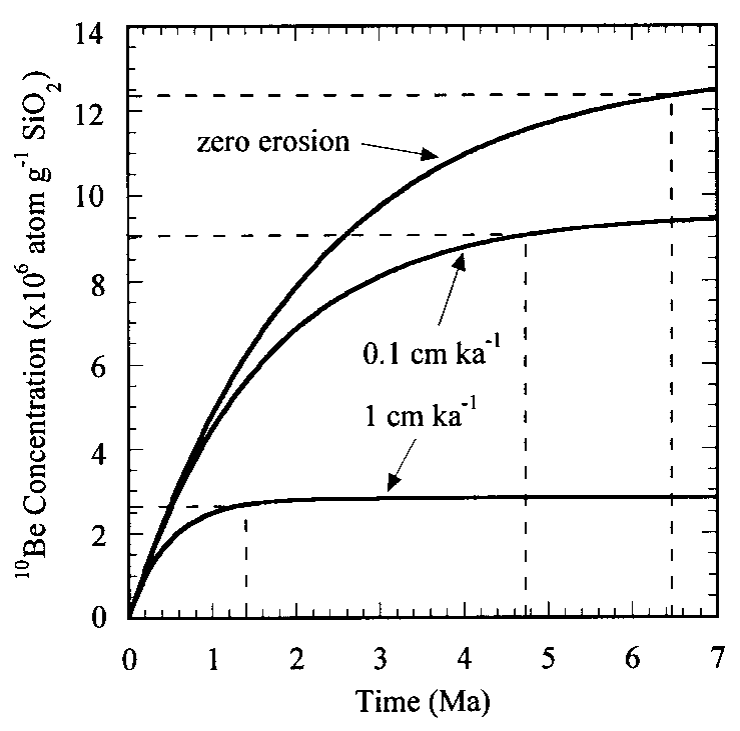

Fig. 1. Increase in surface ${ }^{10}$ Be concentration with time under different steady-state erosion rates calculated using Equation (1) with ${ }^{10}$ Be production rate of 6.0 atoms $^{-1}\left(\mathrm{SiO}_{2}\right) a^{-1}$. Dashed lines intersect concentration curves at $95 \%$ cosmogenic radionuclide saturation in the sample, representing the maximum age currently measurable for given production and erosion rate. 


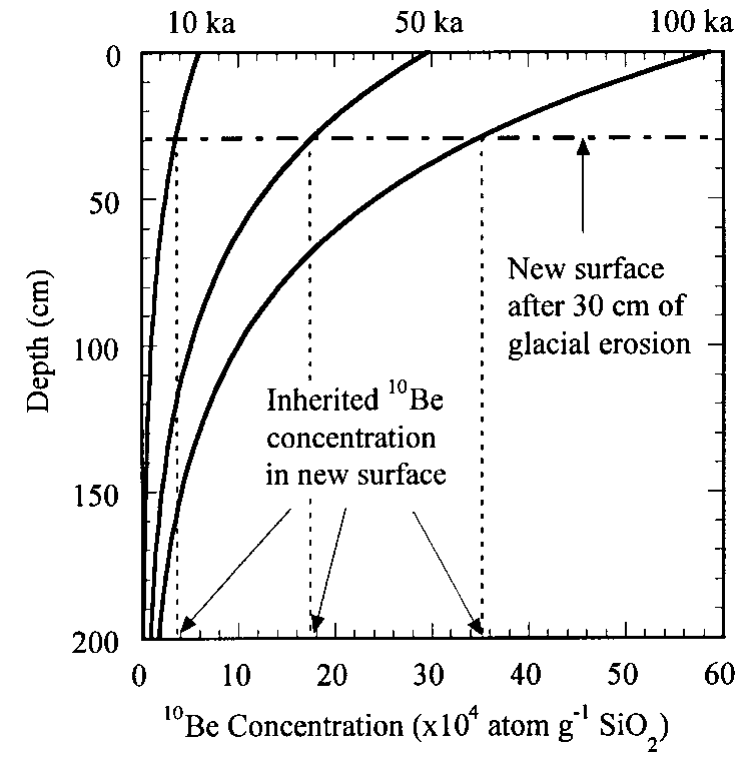

Fig. 2. Exponential decrease in ${ }^{10}$ Be concentration with depth for a surface production rate of 6.0 atoms $^{-1}\left(\mathrm{SiO}_{2}\right) a^{-1}$ and a rock density of $2.75 \mathrm{~g} \mathrm{~cm}^{-3}$ after 10,50 and $100 \mathrm{ka}$ (solid curves). The effect of shallow glacial scouring on inheritance is shown for the case where $30 \mathrm{~cm}$ of bedrock is removed (thick dot-dash line). For example, if $30 \mathrm{~cm}$ is removed after $50 \mathrm{ka}$ of exposure, the new surface has an inherited ${ }^{10}$ Be concentration of $\sim 17.5 \times 10^{4}$ atoms $^{-1}$, equivalent to an apparent exposure age of $\sim 29 \mathrm{ka}$.

ated by nuclear reactions in quartz (Nishiizumi and others, 1986); and ${ }^{36} \mathrm{Cl}$ which is produced by cosmic-ray interactions with ${ }^{35} \mathrm{Cl},{ }^{39} \mathrm{~K}$ and ${ }^{40} \mathrm{Ca}$ (Phillips and others, 1997). The half-lives for ${ }^{10} \mathrm{Be},{ }^{26} \mathrm{Al}$ and ${ }^{36} \mathrm{Cl}$ are: $1.51 \pm 0.03 \times 10^{6} \mathrm{a}$ (Hofmann and others, 1987); $7.05 \pm 0.2 \times 10^{5} \mathrm{a}$ (Norris and others, 1983); and $3.01 \times 10^{5}$ a (Lederer and Shirley, 1978) respectively. Quartz and the target materials for ${ }^{36} \mathrm{Cl}$ are found in a large variety of rocks and sediments making the technique widely applicable.

With prolonged exposure, cosmogenic radionuclides accumulate within exposed rock as a function of time and depth below the surface (Figs 1 and 2). Time elapsed $T$ (years) since initial rock surface exposure can be calculated from cosmogenic nuclide concentrations $N\left(\right.$ atoms $\left.\mathrm{g}^{-1}\right)$ in the sample according to Lal (1991):

$$
N=\frac{P}{\lambda+\mu \varepsilon} e^{-\mu x}\left(1-e^{-(\lambda+\mu \varepsilon) T}\right)+N_{\mathrm{i}} e^{-\lambda T}
$$

where $P$ is the local cosmogenic radionuclide production rate (atoms $\left.\mathrm{g}^{-1} \mathrm{a}^{-1}\right), x$ is depth below the surface $(\mathrm{cm}), \lambda$ is the radioactive decay constant $\left(\mathrm{a}^{-1}\right), \varepsilon$ is the surface-erosion rate $\left(\mathrm{cm} \mathrm{a}^{-1}\right), N_{\mathrm{i}}$ is the inherited concentration of cosmogenic radionuclides (atom $\mathrm{g}^{-1}$ ), $\mu$ is the absorption coefficient $\left(\mathrm{cm}^{-1}\right)$ in the target; $\mu=\rho / \Lambda$ where $\rho$ is the average density of the rock $\left(\mathrm{g} \mathrm{cm}^{-3}\right)$, and $\Lambda$ is the exponential production attenuation length in rocks $\left(150 \mathrm{~g} \mathrm{~cm}^{-2}\right.$; Brown and others, 1992).

Cosmogenic radionuclide measurements require accelerator mass spectrometry (AMS) because cosmogenic nuclide concentrations in a sample are typically $<10^{6}$ atoms $^{-1}$ (Elmore and Phillips, 1987). AMS measurements are made to a precision of $1 \%$ to $7 \%$, where precision is a measure of the exactness with which the result is determined and how reproducible the result is, without reference to what the result means.

\section{UNGERTAINTIES OF COSMOGENIC RADIO- NUCLIDE METHODS}

In addition to AMS measurement precision limits, there are also inherent systematic errors in the use of cosmogenic radionuclides, particularly in sampling and in our current understanding of spatial and temporal variations in cosmogenic radionuclide production rates. The uncertainties resulting from these errors must be estimated and combined with uncertainties related to the statistical distribution of results when multiple samples are analyzed. Systematic uncertainties, unlike analytical ones, are not reduced by additional measurements, and so may dominate overall uncertainty.

The concentration of cosmogenic radionuclides in a sample depends not only on time, but also on production rate integrated over the entire exposure time, depth below the surface, geometry of the sampled surface, surface-erosion rate or burial rate, and the initial cosmogenic radionuclide concentration (Equation (1)). A sampling strategy for the application of cosmogenic radionuclide techniques should be designed to minimize systematic error and uncertainties in subsequent age and erosion determination. To minimize the depth correction required as a result of the exponential decrease in cosmogenic radionuclide production with depth (Fig. 2), samples are usually collected from within $5 \mathrm{~cm}$ of the rock surface. The extent of sample shielding from exposure to cosmic rays by surrounding topography and sample geometry is accounted for in geometric and shielding corrections, based on measuring sample-surface inclination and vertical angles to the horizon. Erosion of a rock surface removes accumulated cosmogenic radionuclides, making calculated exposure ages too young. Burial has the same effect because it shields the surface from cosmic rays. To minimize the impact of burial or erosion, surface samples are selected that have no evidence of erosion since initial exposure and are unlikely to have ever been buried.

The largest systematic uncertainty in surface-exposure ages is the production-rate estimate. The thickness of atmosphere cosmic-ray particles have to penetrate to reach the surface affects the production rate. Thus, at low latitudes and low elevations, surface-production rates are lowest. Similarly, the geomagnetic dipole field shields the Earth from low-energy cosmic rays. This shielding effect is strongest at the magnetic Equator and virtually absent at the magnetic poles (Lal and Peters, 1967). Estimates of production rates have been derived from measured cosmogenic radionuclide concentrations in independently dated surfaces and from theoretical calculations (Tables 1 and 2). For specific localities, most workers adjust the production rate for latitude and altitude using the scaling factors of Lal (1991).

Recently, data from marine cores and the Greenland Icecore Project (GRIP) core have provided a high-resolution correlation between cosmogenic radionuclide production and geomagnetic field-strength variations over the last $200 \mathrm{ka}$ (Frank and others, 1997; Baumgartner and others, 1998), allowing some magnetic corrections to be made. However, several issues related to the systematics of cosmo- 
Table 1. Published ${ }^{36}$ Cl production rates ( sea-level and $\geq 60^{\circ}$ geomagnetic latitude)

\begin{tabular}{|c|c|c|c|c|}
\hline \multirow[t]{3}{*}{ References } & \multicolumn{4}{|c|}{${ }^{36} \mathrm{Cl}$ production by } \\
\hline & spallation of $\mathrm{Ca}$ & spallation of $K$ & thermal neutron capture & muon capture by $\mathrm{Ca}$ \\
\hline & atoms $(\mathrm{g} \mathrm{Ca})^{-1} \mathrm{a}^{-1}$ & atoms $(\mathrm{g} \mathrm{K})^{-1} \mathrm{a}^{-1}$ & fast neutrons $(\mathrm{g} \text { air })^{-1} \mathrm{a}^{-1}$ & atoms $(\mathrm{g} \mathrm{Ca})^{-1} \mathrm{a}^{-1}$ \\
\hline Phillips and others (1996b) & $73.3 \pm 4.9$ & $154 \pm 10$ & $586 \pm 40$ & \\
\hline Stone and others (1996a) & $48.8 \pm 1.7$ & & & $4.8 \pm 1.2$ \\
\hline Stone and others (1996b) & & $185 \pm 15$ & & \\
\hline Stone and others (1998a) & & & & $5.3 \pm 1.0$ \\
\hline Masarik and Reedy (1995) & $46.2^{*}$ & & & \\
\hline
\end{tabular}

* Theoretical calculation.

genic radionuclide production are still being determined (e.g. Gosse and Klein, 1996). These include production-rate coefficients and pre-200 ka fluctuations in the dipole geomagnetic field intensity. After these issues have been resolved, cosmogenic ages calculated on the basis of our present understanding of the controlling factors will need to be revised. It is anticipated that the magnitude of these corrections will not exceed 15\% (Phillips and others, 1997). Systematic production uncertainties do not impact on comparisons between results using the same production-rate estimate. For example, if the aim is to determine the age differences between a series of moraines, cosmogenic radionuclide data can be utilized at the analytical precision of 3-7\%, assuming constant production rate. If production rates vary, that variation must be accounted for.

\section{SURFAGE EXPOSURE AGES AND EROSION RATES}

Surface-exposure dating has been the most widely used cosmogenic radionuclide technique in glacial geomorphology to date, and has proven useful for constraining glacial chronologies in alpine areas (e.g. Phillips and others, 1990, 1996a, b, 1997; Gosse and others, 1995a, b) as well as in ice-

Table 2. Published ${ }^{10}$ Be and ${ }^{26}$ Al production rates (sea-level and $\geq 60^{\circ}$ geomagnetic latitude) and ${ }^{26} \mathrm{Al} /{ }^{10} \mathrm{Be}$ ratios

\begin{tabular}{|c|c|c|c|c|}
\hline \multirow{3}{*}{$\begin{array}{l}\text { Method/ } \\
\text { location }\end{array}$} & \multirow[t]{3}{*}{ Exposure age } & \multicolumn{2}{|c|}{ Production rates } & \multirow{3}{*}{$\begin{array}{c}{ }^{26} \mathrm{Al} /{ }^{10} \mathrm{Be} \\
\text { ratio }\end{array}$} \\
\hline & & ${ }^{10} \mathrm{Be}$ & ${ }^{26} A l$ & \\
\hline & & $\begin{array}{c}\text { atoms } \\
\left(\mathrm{g} \mathrm{SiO}_{2}\right)^{-1} \mathrm{a}^{-1}\end{array}$ & $\begin{array}{c}\text { atoms } \\
\left(\mathrm{g} \mathrm{SiO}_{2}\right)^{-1} \mathrm{a}^{-1}\end{array}$ & \\
\hline Water targets ${ }^{1}$ & $1-2 \mathrm{a}$ & $6.0 \pm 0.3^{\mathrm{a}}$ & & \\
\hline Landslide $^{2}$ & $5.5-13 \mathrm{ka}$ & $5.75 \pm 0.24$ & $37.4 \pm 1.9$ & $6.52 \pm 0.43$ \\
\hline Sierra Nevada rocks ${ }^{3}$ & $11 \mathrm{ka}$ & $6.0 \pm 0.29$ & $36.8 \pm 2.7$ & $6.10 \pm 0.54$ \\
\hline Sierra Nevada rocks ${ }^{1}$ & $13 \mathrm{ka}$ & $5.8^{\mathrm{b}}$ & & \\
\hline Antarctic rocks ${ }^{4}$ & $\leq 2.5 \mathrm{Ma}$ & $6.4 \pm 1.5^{\mathrm{c}}$ & $41.7 \pm 5.9^{c}$ & $6.5 \pm 1.3$ \\
\hline Antarctic rocks ${ }^{5}$ & $\geq 4 \mathrm{Ma}$ & 6.13 & & \\
\hline Antarctic rocks ${ }^{6}$ & & & $35.2 \pm 2$ & \\
\hline Theoretical $^{7}$ & a few Ma & 5.97 & 36.1 & 6.05 \\
\hline
\end{tabular}

References: 1. Nishiizumi and others (1996); 2. Kubik and others (1998); 3. Nishiizumi and others (1989); 4. Brown and others (1991); 5. Nishiizumi and others (1991a); 6. Brook and others (1996a); 7. Masarik and Reedy (1995).

a. Production rate extrapolated to an exposure time of $10 \mathrm{ka}$.

b. Recalculated from Nishiizumi and others (1996) with new estimate of exposure age and use of geographic instead of geomagnetic latitude.

c. Only the smaller of the asymmetric uncertainties quoted in Brown and others (1991) are listed here. sheet dominated terrain such as Antarctica (Ivy-Ochs and others, 1995; Fabel and others, 1997) and northern Europe (e.g. Brook and others, 1996b). Unlike other techniques, surface-exposure dating can be used to date glacial events directly because it avoids the inaccuracies of methods which produce bracketing ages by dating prior or subsequent events, such as burial of organic matter by moraine. The time range of the method is in the order of a thousand to several million years (Fig. 1). Age limits depend on which isotope is being used, how fast the sampled surface is eroding, and local cosmogenic radionuclide production rates (e.g. Brown and others, 1992; Nishiizumi and others, 1993; Bierman, 1994).

Using Equation (1) to calculate exposure time $(T)$ from a measured cosmogenic radionuclide concentration $(N)$ in a sample requires that the post-exposure steady-state erosion rate $(\varepsilon)$ is known. For surfaces that show evidence of very little postglacial erosion, such as intact striations and glacial polish, a post-exposure steady-state erosion rate of zero is assumed. If independent erosion-rate evidence is not available, there is no unique solution to Equation (1), rather, the inferred results consist of paired erosion rates and ages. If the exposure time can be independently constrained, the cosmogenic radionuclide concentration can be used to calculate the post-exposure steady-state erosion rate for the surface.

Although independent age control is often not available, steady-state bedrock-erosion rates can be calculated. Because production decreases exponentially with depth below the surface (Fig. 2), the accumulated cosmogenic radionuclide concentration in a mineral grain records the speed with which that grain has been uncovered; slower erosion rates imply longer exposure times near the surface, and thus higher concentrations. Lal (1991) showed that the cosmogenic radionuclide concentration $N$, in a steadily eroding outcrop surface, is inversely proportional to the outcrop's erosion rate $\varepsilon$ :

$$
N=\frac{P}{\lambda+\mu \varepsilon}
$$

The radionuclide concentration $N$ averages the erosion rate over a time-scale of order $1 / \mu \varepsilon$, the time required to erode a layer of thickness $1 / \mu$ from the surface. Equation (2) assumes that the half-life, $\lambda$, is much longer than $1 / \mu \varepsilon$. Because cosmogenic radionuclides are insensitive to recent changes in erosion rates, they are particularly useful for estimating long-term rates of erosion (Brook and others, 1996b; Granger and others, 1996).

Additionally, Lal (1991) showed that the cosmogenic 
radionuclide ratio derived from measurement of two cosmogenic radionuclides in the same sample varies with exposure time and erosion rate because of the difference in their respective decay rates (see section on Burial dating below). Hence, in theory it is possible to simultaneously calculate an erosion rate and exposure age for a sample by measuring the concentration of two cosmogenic radionuclides. The applicability of this has only been demonstrated for areas with long exposure histories and very slow erosion rates (e.g. Nishiizumi and others, 1993).

\section{EROSION AND INHERITANGE}

A concern in exposure-age dating in glaciated landscapes is the extent to which insufficient glacial erosion might yield erroneous deglaciation ages due to remnant cosmogenic radionuclide concentrations in exposed surfaces (Fabel and others, 1997). This is a concern if the exposure age "clock" is only partially reset because erosion does not remove all of the surface and near-surface rock in which cosmogenic radionuclides accumulated prior to the glacial event. However, accounting for this problem provides a unique new opportunity to back-calculate the amount of rock lost due to erosion (Horn and others, 1996; Briner and Swanson, 1998). We are applying this approach to determine the spatial distribution of valley-scale glacial erosion based on the exponential decrease in cosmogenic radionuclide concentration with depth in a rock surface (Fig. 2) and the inherited cosmogenic radionuclide concentration in the sample (Fabel and others, 1998). Inheritance refers to the remnant cosmogenic radionuclide concentration from a prior exposure history. For example, for exposed bedrock with a density of $2.75 \mathrm{~g} \mathrm{~cm}^{-3}$, the cosmogenic radionuclide production rate at a depth of $\sim 175 \mathrm{~cm}$ is $<5 \%$ of the surface-production rate and is not measurable with current AMS precision. If a surface which has been exposed for a few thousand years is overridden by ice which erodes in excess of $\sim 175 \mathrm{~cm}$ of bedrock, the existing cosmogenic radionuclide signal is $95 \%$ removed leaving a "fresh" surface exposed after retreat. If, on the other hand, glacial erosion removes $<175 \mathrm{~cm}$ of rock, the subsequently exposed surface contains a measurable cosmogenic radionuclide concentration inherited from prior exposure (Fig. 2).

Inherited concentrations can be calculated if the ages of the penultimate and final deglaciation can be constrained, either independently or from multiple surface-exposure ages. The difference between the deglaciation age and the age given by the samples with inheritance provides the concentration of inherited cosmogenic radionuclides, and the difference between the penultimate and final deglaciation limits is the time available for erosion. Using the exponential decrease in cosmogenic radionuclide concentration with depth (Fig. 2), it is possible to back-calculate how much rock had to be eroded to leave the sampled surface with the inherited cosmogenic radionuclide concentration:

$$
x=\frac{\Lambda}{\rho} \ln \left(\frac{N_{\text {meas }}-N_{\mathrm{deg}}}{N_{\text {prior }}-N_{\mathrm{deg}}}\right)
$$

where $x$ is the depth of rock removed, $N_{\text {meas }}$ is the measured cosmogenic radionuclide concentration, and $N_{\mathrm{deg}}$ and $N_{\text {prior }}$ are the modeled cosmogenic radionuclide concentrations (using Equation (1)) for the penultimate and final deglaciation ages.

For example, we have measured ${ }^{10} \mathrm{Be}$ and ${ }^{26} \mathrm{Al}$ in bedrock samples collected from a valley profile in the Wind River Range, Wyoming. The samples were striated and polished, indicating very minor erosion since the last deglaciation. The erosion rates obtained from calculated cosmogenic radionuclide inheritance in the samples for the period between the penultimate and last glaciation range from $>3.0 \mathrm{~cm} \mathrm{ka}^{-1}$ in the valley bottom to $<0.22 \mathrm{~cm} \mathrm{ka}^{-1}$ near the upper limit of the Last Glacial Maximum ice in the valley (unpublished data). The calculations assume that the penultimate Bull Lake glaciation (Phillips and others, 1997) left a comogenic radionuclide-free surface and the youngest surface-exposure ages provide the final deglaciation age. From the available data, it is not possible to determine if the calculated erosion rates are purely glacial or if they are a mixture between subaerial (during the Interglacial) and glacial erosion. In other applications of this concept, Briner and Swanson (1998) calculated glacial erosion rates for a large roche moutonnée in the area of Puget Sound, Washington, U.S.A., using ${ }^{36} \mathrm{Cl}$ inheritance. Erosion-rate data for the last glacial advance yielded 9$35 \mathrm{~cm} \mathrm{ka}^{-1}$ from the stoss side, and in excess of $63-72 \mathrm{~cm} \mathrm{ka}^{-1}$ on summit surfaces, while the quarried lee region yielded deglaciation ages and corresponding erosion depths of $\geq 2 \mathrm{~m}$.

\section{BURIAL DATING}

One cosmogenic radionuclide application that has received relatively little attention in glacial geomorphology so far is dating sediment burial using the radioactive decay of ${ }^{26} \mathrm{Al}$ and ${ }^{10} \mathrm{Be}$. The method has been used to date sediments in river terraces, alluvial fans and caves (Granger and others, 1996; 1997), and relies on the fact that ${ }^{26} \mathrm{Al}$ is produced sixtimes faster than ${ }^{10} \mathrm{Be}$, regardless of the absolute production rate (Table 2, column 5). Thus if a quartz-bearing rock accumulates ${ }^{26} \mathrm{Al}$ and ${ }^{10} \mathrm{Be}$ while exposed at the surface, then its ${ }^{26} \mathrm{Al} /{ }^{10} \mathrm{Be}$ ratio will be six. If this rock is subsequently buried deep enough that it is completely shielded, its ${ }^{26} \mathrm{Al} /{ }^{10} \mathrm{Be}$ ratio will diminish over time because ${ }^{26} \mathrm{Al}$ decays faster than ${ }^{10} \mathrm{Be}$. Thus, the departure of the ${ }^{26} \mathrm{Al} /{ }^{10} \mathrm{Be}$ ratio in the buried rock from an initial value of six can be used to determine the time since burial.

Following Lal (1991) and Granger and others (1997), the ${ }^{26} \mathrm{Al} /{ }^{10} \mathrm{Be}$ ratio $\left(N_{26} / N_{10}\right)$ in a steadily eroding outcrop will change with erosion rate $\varepsilon$ as follows:

$$
\left(\frac{N_{26}}{N_{10}}\right)=\frac{P_{26}\left(\lambda_{10}+\mu \varepsilon\right)}{P_{10}\left(\lambda_{26}+\mu \varepsilon\right)}
$$

where the suffixes 26 and 10 make the symbols (defined in Equation (1)) specific to ${ }^{26} \mathrm{Al}$ and ${ }^{10} \mathrm{Be}$ respectively. For erosion rates much faster than $\lambda_{26} / \mu$, the ${ }^{26} \mathrm{Al} /{ }^{10} \mathrm{Be}$ ratio approaches $\left(N_{26} / N_{10}\right)=P_{26} / P_{10}=\sim 6.0$ (Table 2 , column 5); for erosion rates much slower than $\lambda_{10} / \mu$, it approaches $\left(P_{26} \lambda_{10} / P_{10} \lambda_{26}=\sim 2.7\right.$ (Fig. 3). When minerals exposed near the Earth's surface are shielded from cosmic rays (e.g. by burial beneath a till), then the cosmogenic radionuclide production ceases and ${ }^{26} \mathrm{Al}$ and ${ }^{10} \mathrm{Be}$ decay according to:

$$
\begin{aligned}
& N_{26}=\left(N_{26}\right)_{\mathrm{i}} e^{-\lambda_{26} T_{\text {burial }}} \\
& N_{10}=\left(N_{10}\right)_{\mathrm{i}} e^{-\lambda_{10} T_{\text {burial }}}
\end{aligned}
$$

where $T_{\text {burial }}$ is the time since burial and $\left(N_{26}\right)_{\mathrm{i}}$ and $\left(N_{10}\right)_{\mathrm{i}}$ represent initial ${ }^{26} \mathrm{Al}$ and ${ }^{10} \mathrm{Be}$ concentrations. Because ${ }^{26} \mathrm{Al}$ 


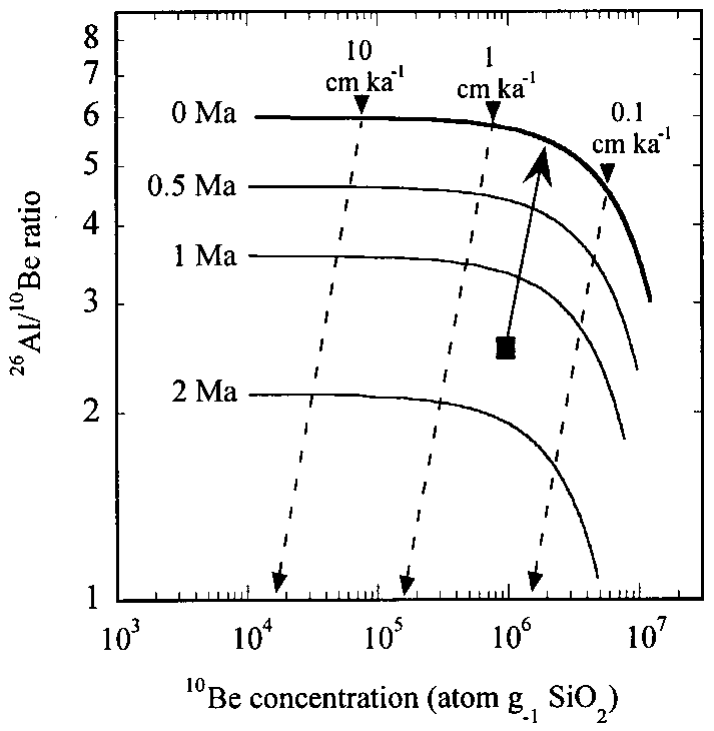

Fig. $3 .{ }^{26} \mathrm{Al} /{ }^{10} \mathrm{Be}$ ratio plotted against ${ }^{10} \mathrm{Be}$ concentration (after Granger and others, 1997). The 0 ma curve represents the ${ }^{26} \mathrm{Al} /{ }^{10}$ Be ratio in a steadily eroding rock, as determined by Equation (4). Erosion rates are shown from $0.1 \mathrm{~cm} \mathrm{ka}^{-1}$, calculated for ${ }^{10}$ Be production rate of 6.0 atoms $g^{-1}\left(\mathrm{SiO}_{2}\right) a^{-1}$. When a sample is shielded from cosmic rays, radioactive decay causes the ${ }^{26} \mathrm{Al} /{ }^{10} \mathrm{Be}$ ratio to decline parallel to the straight dashed lines, according to Equation (6). Isochrons are shown as thin curves (labeled Ma). The black square is a hypothetical sample with a measured ${ }^{26} \mathrm{Al}$ and ${ }^{10}$ Be concentration. The ${ }^{26} \mathrm{Al} /{ }^{10} \mathrm{Be}$ ratio and ${ }^{10} \mathrm{Be}$ concentration indicate a burial age of $\sim 1.5 \mathrm{Ma}$. The pre-burial erosion rate may be calculated by backtracking ${ }^{26} \mathrm{Al} /{ }^{10}$ Be ratios parallel to the dashed decay lines (large arrow) to intercept the 0 Ma exposure line, providing a steady-state erosion estimate of $0.1-1 \mathrm{~cm} \mathrm{ka}^{-1}$ for this sample.

decays faster than ${ }^{10} \mathrm{Be}$, the ratio $N_{26} / N_{10}$ decreases exponentially over time (Fig. 3):

$$
\frac{N_{26}}{N_{10}}=\left(\frac{N_{26}}{N_{10}}\right)_{\mathrm{i}} e^{-\left(\lambda_{26}-\lambda_{10}\right) T_{\text {burial }}}
$$

Equations (4)-(6) can be solved iteratively and can be used to estimate burial times and pre-burial erosion rates (Granger and others, 1997).

Geological requirements for the method to be applicable are simply that: (1) quartz must be exposed at the surface for long enough to accumulate measurable cosmogenic radionuclide concentrations (typically $>10 \mathrm{ka}$ ); (2) the quartz must be buried quickly with respect to radioactive decay; (3) the quartz must be buried deeply with respect to cosmic-ray penetration (typically $>5 \mathrm{~m}$ ); and (4) the sediment must have a simple history of exposure prior to burial (Granger and others, 1997), i.e. no inherited cosmogenic signal.

One possible glaciological application of burial dating is to determine the age of material buried by till. This is useful because the time of till deposition may be considerably different from the time the till is exposed by glacial retreat. Additionally, there may be situations where multiple phases of till deposition prevent surface-exposure dating of all but the most recent depositional event. Burial dating till material itself is problematic, since the material has probably only experienced limited exposure. However, the burial-dating method can be applied to sediments or palaeosols which are likely to have been exposed in excess of $10 \mathrm{ka}$ prior to being buried by the till. By determining the burial age of these types of samples, it is possible to obtain an age for till deposition. Precision of burial dating using ${ }^{26} \mathrm{Al}$ and ${ }^{10} \mathrm{Be}$ is limited to $\sim 200 \mathrm{ka}$, thus burial dating is mainly useful for dating older events which have previously been difficult to date, or for which only limiting ages, such as palaeomagnetic dates, exist. The method is currently being successfully applied to buried fluvial and lacustrine sediments from palaeochannels and proglacial lakes to determine which ice-sheet advances caused the major drainage rearrangements documented in the mid-west of the U.S.A. (Granger and Smith, 1998).

\section{SHIELDING AND COMPLEX EXPOSURE HISTORIES}

Although surface-exposure ages, erosion rates, and burial ages can be obtained for well-constrained situations, complex surface-exposure histories are problematic. Interpretation of cosmogenic radionuclide concentrations is much more difficult if a surface has experienced multiple exposure periods, erosion and periods of burial. Current exposureage calculations are usually based on models that assume steady-state erosion and free-surface exposure, i.e. without shielding of the surface by sediment or ice in the past. Thus, reported ages are generally based on the simplest likely geomorphological history.

Surface shielding lowers the cosmogenic radionuclide production rate. If a surface has been exposed, subsequently shielded and only recently re-exposed, then the cosmogenic radionuclide concentration will have decreased by radioactive decay during the shielding period. In theory, the ratio of two nuclides with different half-lives could be used to distinguish between continuous exposure at the surface and periodic shielding (personal communication from D. Lal, 1998). This may have considerable potential for constraining the duration of ice-sheet occupation.

To illustrate the effect of multiple-shielding events on the cosmogenic radionuclide concentration in a bedrock surface, consider a bimodal cyclic exposure history of a surface which is exposed for $T_{1}$ years followed by shielding for $T_{2}$ years. The surface-erosion rate is assumed to be zero. For multiple cycles with full exposure for time $T_{1}$, followed by partial exposure at $K$ times the full intensity for a time period $T_{2}$, with a radioactive decay constant $\lambda$, and surface production rate $P$, the cosmogenic radionuclide concentration attains a value $C_{\mathrm{n}}$, after $n$ cycles:

$$
\begin{aligned}
& C_{\mathrm{n}}=\frac{P}{\lambda}\left[\frac{1-e^{-\mathrm{n} \lambda\left(T_{1}+T_{2}\right)}}{1-e^{-\mathrm{n} \lambda\left(T_{1}+T_{2}\right)}} \times\right. \\
& {\left.\left[e^{-\lambda T_{2}}\left(1-e^{-\lambda T_{1}}\right)\right]+K\left(1-e^{-\lambda T_{2}}\right)\right] }
\end{aligned}
$$

where $K=1$ represents no shielding (i.e. there are no glacial periods in the record) and $K=0$ represents full shielding during glacial periods. These simulations show that shielding history produces a change in cosmogenic radionuclide ratios (Fig. 4). Assuming full shielding during glacial periods (at least $5.5 \mathrm{~m}$ of ice), with multiple radionuclides we can in theory solve for $T_{2}$, the portion of time ice-shielding has been effective, i.e. we have the possibility of constraining the lengths of glacial periods using cosmogenic radionuclide techniques.

The minimum measurable difference in the cosmogenic radionuclide ratios resulting from multiple-exposure his- 


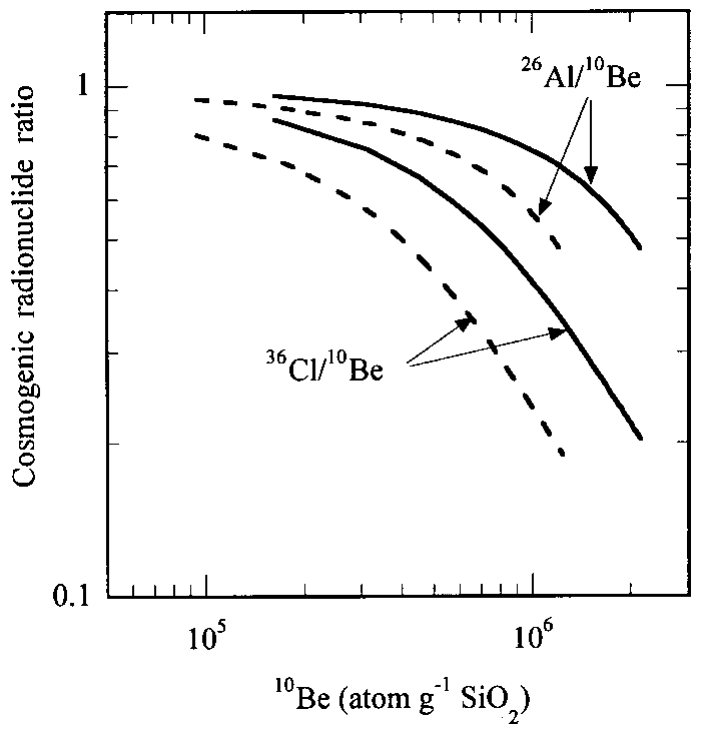

Fig. $4 .{ }^{26} \mathrm{Al} /{ }^{10} \mathrm{Be}$ and ${ }^{36} \mathrm{Cl} /{ }^{10} \mathrm{Be}$ ratios plotted against ${ }^{10} \mathrm{Be}$ concentration. The solid curves show the cosmogenic radionuclide buildup in a rock surface calculated using Equation (7) for 50 cycles of $T_{1}=80 \mathrm{ka}$ and $T_{2}=30 \mathrm{ka}$ with both $T_{1}$ and $\mathrm{T}_{2}$ at full production (no shielding). These curves are identical to the steady-state erosion curve calculated in Figure 3 using Equation (4) except that here the erosion rate is zero and surface production rates for ${ }^{10} \mathrm{Be},{ }^{26} \mathrm{Al}$ and ${ }^{36} \mathrm{Cl}$ are 1 atoms $\mathrm{g}^{-1} \mathrm{a}^{-1}$. The dashed curves are calculated in the same way, but with $\mathrm{T}_{2}$ at zero production ( shielded). Shielding the surface during part of its history decreases the ${ }^{26} \mathrm{Al} /{ }^{10} \mathrm{Be}$ and ${ }^{36} \mathrm{Cl} /{ }^{10} \mathrm{Be}$ ratios in the samples when compared to a free exposure history. Note the effect is more dramatic for ${ }^{10} \mathrm{Be}$ and ${ }^{36} \mathrm{Cl}$. This is because of the larger difference in the radioactive decay rate between ${ }^{10}$ Be ratio ${ }^{36} \mathrm{Cl}$ when compared to ${ }^{10} \mathrm{Be}$ and ${ }^{26} \mathrm{Al}$.

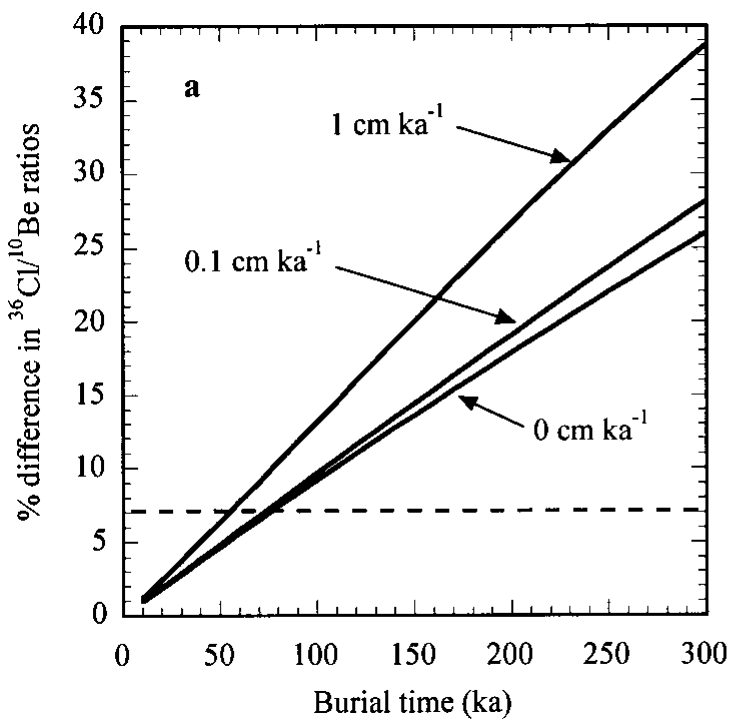

tories versus an exposure history without shielding is $\sim 7 \%$. With this in mind, we set up an exposure model to compare expected cosmogenic radionuclide ratios for continuous and complex exposure histories. The model takes into account pre-burial, burial, and post-burial time, subaerial erosion during non-glaciated times, and glacial erosion by the burying ice. The cosmogenic radionuclide concentrations for a surface which experiences burial through part of its exposure history $\left(N_{\text {complex }}\right)$ and for a surface which has not been shielded during the same time interval $\left(N_{\text {simple }}\right)$ are calculated for each individual isotope according to:

$$
\begin{gathered}
N_{\text {complex }}=\frac{P}{\lambda+\mu \varepsilon_{\mathrm{s}}}\left[\begin{array}{l}
\left(1-e^{-\left(\lambda+\mu \varepsilon_{\mathrm{s}}\right) T_{\text {pre }}}\right) e^{-\left(\lambda+\mu \varepsilon_{\mathrm{g}}\right) T_{\text {burial }}} \\
+\left(1-e^{-\left(\lambda+\mu \varepsilon_{\mathrm{s}}\right) T_{\text {post }}}\right)
\end{array}\right] \\
N_{\text {simple }}=\frac{P}{\lambda+\mu \varepsilon_{\mathrm{s}}}\left[\begin{array}{c}
\left(1-e^{-\left(\lambda+\mu \varepsilon_{\mathrm{s}}\right) T_{\text {pre }}}\right) e^{-\left(\lambda+\nu \varepsilon_{\mathrm{s}}\right) T_{\text {burial }}} \\
\left.+1-e^{-\left(\lambda+\mu \varepsilon_{\mathrm{s}}\right) T_{\text {burial }}}\right) \\
+e^{-\left(\lambda+\mu \varepsilon_{\mathrm{s}}\right) T_{\text {post }}}+\left(1-e^{\left.-\left(\lambda+\mu \varepsilon_{\mathrm{s}}\right) T_{\text {post }}\right)}\right.
\end{array}\right]
\end{gathered}
$$

where $\varepsilon_{\mathrm{s}}$ and $\varepsilon_{\mathrm{g}}$ are subaerial and glacial-erosion rate $\left(\mathrm{cm} \mathrm{ka}^{-1}\right)$ respectively, and $T_{\text {pre, }} T_{\text {burial }}$ and $T_{\text {post }}$ are the pre-burial, burial and post-burial times (a) respectively. All other symbols are defined in Equation (1).

The results shown in Figure 5 are for ${ }^{36} \mathrm{Cl} /{ }^{10} \mathrm{Be}$ ratios and provide minimum requirements for the method to be applicable since ${ }^{36} \mathrm{Cl} /{ }^{10} \mathrm{Be}$ is more sensitive to complex histories then ${ }^{26} \mathrm{Al} /{ }^{10} \mathrm{Be}$ (Fig. 4). The results of the modeling indicate that to get a measurable difference in the ${ }^{36} \mathrm{Cl} /{ }^{10} \mathrm{Be}$ ratio requires a minimum burial time of $\sim 70 \mathrm{ka}$. Pre-burial erosion reduces this minimum burial time (Fig. 5a). Glacial erosion, although reducing the cosmogenic radionuclide concentration in the surface, does not affect the minimum burial time because the ${ }^{36} \mathrm{Cl} /{ }^{10} \mathrm{Be}$ ratio depends on radioactive decay which is constant regardless of the subglacial ero-

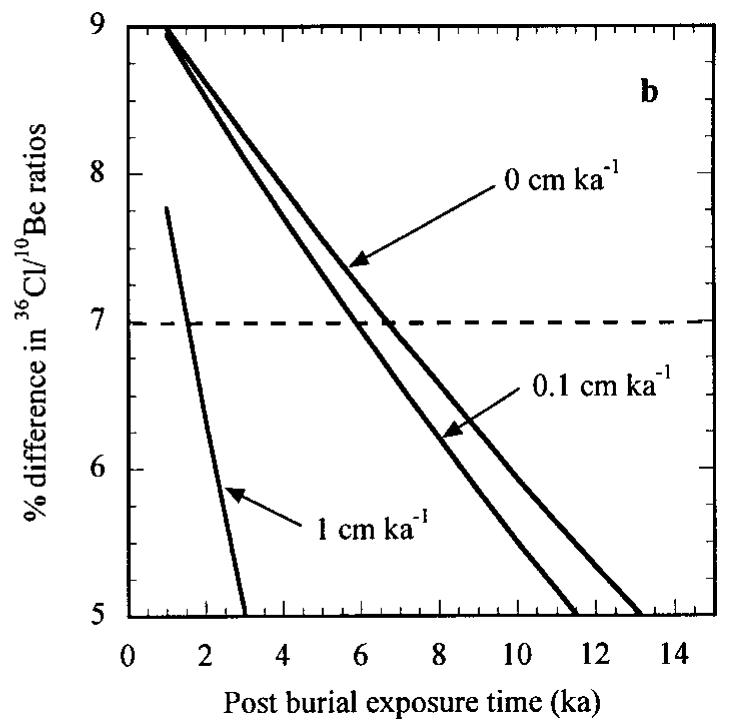

Fig. 5. Sensitivity plots of a complex exposure model to length of burial ( a) and length of post-burial exposure ( $b$ ). Percentage difference in ${ }^{36} \mathrm{Cl} /{ }^{10} \mathrm{Be}$ ratios is the difference in ${ }^{36} \mathrm{Cl} /{ }^{10} \mathrm{Be}$ for a surface which has been exposed continuously, compared to a surface which has experienced burial. The horizontal dashed line marks the 7\% ratio difference which is the minimum requirement for AMS. 5a) Pre-burial time set at $50 \mathrm{ka}$ and post-burial time at $0 \mathrm{ka}$. Labels denote subaerial-erosion rates during pre-burial exposure. Plots including glacial erosion during burial are covered by the $0 \mathrm{~cm} \mathrm{ka}^{-1}$ line (see text). 5b) Pre-burial and burial times set at $100 \mathrm{ka}$. Labels denote glacial-erosion rates for the duration of burial. Note, even with zero erosion, the percentage difference in ${ }^{36} \mathrm{Cl} /{ }^{10}$ Be ratio drops below $7 \%$ after $\sim 7 \mathrm{ka}$. 
sion rate. Obviously, if glacial erosion exceeds $\sim 175 \mathrm{~cm}$, all inherited cosmogenic radionuclide information is lost. The most dramatic effect, and ultimately the critical factor influencing the feasibility of applying the complex exposure model in the real world, is the post-burial exposure time (Fig. 5b). The ${ }^{36} \mathrm{Cl} /{ }^{10} \mathrm{Be}$ ratio will only be measurable if the surface has experienced limited post-burial exposure $(<\sim 7 \mathrm{ka}$ for a burial time of $100 \mathrm{ka}$ ) because renewed cosmogenic radionuclide accumulation rapidly obliterates the ${ }^{36} \mathrm{Cl} /{ }^{10} \mathrm{Be}$ signal inherited after the burial event. This is enhanced by glacial erosion since it reduces the inherited cosmogenic radionuclide concentration. Subaerial erosion after burial has a buffering effect because the net rate of cosmogenic radionuclide accumulation in the surface is reduced (Fig. 5b). In summary, measurable differences in ${ }^{36} \mathrm{Cl} /{ }^{10} \mathrm{Be}$ ratios between simple (continuous) surface exposure and more complex exposure histories will only occur if the burial time exceeds $\sim 70 \mathrm{ka}$ and the surface has been exposed for less than a few thousand years. This suggests the technique might best be applied to surfaces that are still buried by till and thus have no complications resulting from recent exposure.

There are additional problems in using ${ }^{36} \mathrm{Cl}$ and ${ }^{10} \mathrm{Be}$ because they are not obtained from the same mineral and the ${ }^{36} \mathrm{Cl}$ production rates are not as well constrained as those for ${ }^{10} \mathrm{Be}$. Nonetheless, testing of this technique is in progress on samples collected in northern Sweden where Kleman and Stroeven (1997) have mapped palaeosurfaces which appear to have been buried by non-erosive ice for the last $110 \mathrm{ka}$, and which have only recently been deglaciated $(<8.5 \mathrm{ka})$. Although this deglaciation age is greater than the minimum set by the complex history model, technical improvements in AMS may reduce the limiting 7\% difference in the ${ }^{36} \mathrm{Cl} /{ }^{10} \mathrm{Be}$ ratios.

\section{CONGLUSION}

Cosmogenic radionuclide techniques have great potential for addressing numerous chronological and process problems in glaciology and glacial geomorphology. Standard surface-exposure dating provides a means for establishing glacial chronologies directly from deposits and surfaces created by glacial events over time-scales of thousands to millions of years. In addition to such established uses, there are as yet untapped cosmogenic radionuclide applications for glaciology and glacial geomorphology. The burial age of previously exposed sediments, derived from the ratio of two cosmogenic radionuclides, can provide chronological control for glacial advances and till deposition. This provides the potential for constraining glaciological models of former valley glaciers and ice sheets. In places where both cosmogenic radionuclide inheritance and independent age control exist, the rate, spatial patterns, and magnitude of glacial erosion can be determined from single cosmogenic radionuclide measurements. This provides the potential for constraining models that link ice dynamics and erosion processes.

The usefulness of the techniques is somewhat tempered by the limitations inherent in the methods. Age errors for surface-exposure dating lie in the $\pm 15 \%$ range due to analytical and systematic uncertainties. Burial dating is only feasible for samples which have initial cosmogenic radionuclide concentrations equivalent to $>10 \mathrm{ka}$ exposure. To obtain a measurable change in the cosmogenic radionuclide ratio burial time has to exceed $\sim 70 \mathrm{ka}$ for ${ }^{36} \mathrm{Cl} /{ }^{10} \mathrm{Be}$ and $\sim 200 \mathrm{ka}$ for ${ }^{26} \mathrm{Al} /{ }^{10} \mathrm{Be}$. Complex exposure histories may only be determined if burial times are long and the length of the post-burial exposure time is short. Where glacial erosion has completely removed the cosmogenic radionuclide signal, the data provide a minimum estimate of the depth of rock removed.

Despite these limitations, the usefulness of cosmogenic radionuclide techniques has been demonstrated by many applications that have yielded important new results. Some of these, as well as potential future applications of cosmogenic radionuclide techniques in glacial geomorphology and glaciology have been outlined here. However, as with any recently established and currently developing technique, there are still relatively few workers in this field. Thus there are considerable opportunities for glaciologists and geomorphologists to make significant new advances by being the first to apply this method to address classic problems in their area of interest.

\section{ACKNOWLEDGEMENTS}

D. Granger and two anonymous reviewers are thanked for valuable comments. The work presented here is funded by United States National Science Foundation grant SBR 9631437.

\section{REFERENCES}

Baumgartner, S., J. Beer, J. Masarik, G. Wagner, L. Meynadier and H.-A. Synal. 1998. Geomagnetic modulation of the ${ }^{36} \mathrm{Cl}$ flux in the GRIP ice core, Greenland. Science, 279(5355), 1330-1332.

Bierman, P. R. 1994. Using in situ produced cosmogenic isotopes to estimate rates of landscape evolution: a review from the geomorphic perspective. 7. Geophys. Res., 99 (B7), 13,885-13,896.

Briner, J. P. and T.W. Swanson. 1998. Using inherited cosmogenic ${ }^{36} \mathrm{Cl}$ to constrain glacial erosion rates of the Cordilleran ice sheet. Geology, 26(1),3-6.

Brook, E. J., E. T. Brown, M. D. Kurz, G. Raisbeck and F. Yiou. 1996a. An Antarctic perspective on in-situ cosmogenic nuclide production. Radiocarbon, $38(1), 150$.

Brook, E. J., A. Nesje, S. J. Lehman, G. M. Raisbeck and F. Yiou. 1996b. Cosmogenic nuclide exposure ages along a vertical transect in western Norway: implications for the height of the Fennoscandian ice sheet. Geology, 24(3), 207-210.

Brown, E. T., J. M. Edmond, G. M. Raisbeck, F. Yiou, M. D. Kurz and E. J. Brook. 1991. Examination of surface exposure ages of Antarctic moraines using in situ produced ${ }^{10} \mathrm{Be}$ and ${ }^{26} \mathrm{Al}$. Geochim. Cosmochim. Acta, 55(8), 2269-2283.

Brown, E.T., E. J. Brook, G. M. Raisbeck, F. Yiou and M. D. Kurz. 1992. Effective attentuation length of cosmic rays producing 10-Be and 26-Al in quartz: implications for exposure dating. Geophys. Res. Lett., 19(4), 369-372.

Cerling, T. E. 1990. Dating geomorphic surfaces using cosmogenic ${ }^{3} \mathrm{He}$. Quat. Res., 33(2), 148-156.

Cerling, T. E. and H. Graig. 1994. Geomorphology and in situ cosmogenic isotopes. Annu. Rev. Earth Planet. Sci., 22, 273-317.

Craig, H. and R. J. Poreda. 1986. Cosmogenic ${ }^{3} \mathrm{He}$ in terrestrial rocks: the summit lavas of Maui. Proc. Nat. Acad. Sci., 83(7), 1970-1974.

Davis, P. T., P. R. Bierman, K. A. Marsella, M.W. Caffee and J. R. Southon. 1999. Cosmogenic analysis of glacial terrains in the eastern Canadian Arctic: a test for inherited nuclides and the effectiveness of glacial erosion. Ann. Glaciol., 28 (see paper in this volume).

Elmore, D. and F. M. Phillips. 1987. Accelerator mass spectrometry for measurement of long-lived radioisotopes. Science, 236(4801), 543-550.

Fabel, D., J. Stone, L. K. Fifield and R. G. Cresswell. 1997. Deglaciation of the Vestfold Hills, East Antarctica: preliminary evidence from exposure dating of three subglacial erratics. In Ricci, C. A., ed. The Antarctic region: geological evolution and processes. Siena, Museo Nazionale dell' Antartide, 829-834. (Terra Antarctica Publication.)

Fabel, D. and 6 others. 1998. Spatial patterns of glacial erosion and glacial chronology in alpine valleys from cosmogenic radionuclide measure- 
ments. [Abstract.] EOS, 79(17), Spring Meeting Supplement, S80.

Frank, M., B. Schwartz, S. Baumann, P.W. Kubik, M. Suter and A. Mangini. 1997. A $200 \mathrm{kyr}$ record of cosmogenic radionuclide production rate and geomagnetic field intensity from ${ }^{10} \mathrm{Be}$ in globally stacked deep-sea sediments. Earth Planet. Sci. Lett., 149(1-4), 121-129.

Gosse, J. and J. Klein. 1996. Production rate of in-situ cosmogenic ${ }^{10}$ Be in quartz at high altitude and mid-latitude. Radiocarbon, 38(1), 154.

Gosse, J. C., J. Klein, E. B. Evenson, B. Lawn and R. Middleton. 1995a. Beryllium-10 dating of the duration and retreat of the last Pinedale glacial sequence. Science, 268(5215), 1329-1333.

Gosse, J.C., E. B. Evenson, J. Klein, B. Lawn and R. Middleton. 1995b. Precise cosmogenic ${ }^{10} \mathrm{Be}$ measurements in western North America: support for a global Younger Dryas cooling event. Geology, 23(10), 877-880.

Granger, D. E. and A. L. Smith. 1998. Early Laurentide glaciation and creation of Ohio River dated by radioactive decay of cosmogenic Al-26 and Be-10 in proglacial sediments. Geol. Soc. Am. Abstr. Programs, 30(2), A298.

Granger, D. E., J.W. Kirchner and R. Finkel. 1996. Spatially averaged longterm erosion rates measured from in situ produced cosmogenic nuclides in alluvial sediments. F. Geol., 104(3), 249-257.

Granger, D. E., J.W. Kirchner and R. Finkel. 1997. Quaternary downcutting rate of the New River, Virginia, measured from differential decay of cosmogenic ${ }^{26} \mathrm{Al}$ and ${ }^{10} \mathrm{Be}$ in cave-deposited alluvium. Geology, 25(2), 107-110.

Hofmann, H. J. and 8 others. 1987. ${ }^{10}$ Be: half-life and AMS-standards. Nucl. Instrum. Methods, Ser. B, 29,32-36..

Horn, L., J. Harbor, D. Elmore, P. Sharma and A. Dunne. 1996. Using cosmogenic radionuclide concentrations to determine glacial erosion across alpine valleys. Radiocarbon, 38(1), 49-50.

Ivy-Ochs, S., C. Schlüchter, P.W. Kubik, B. Dittrich-Hannen and J. Beer. 1995. Minimum ${ }^{10} \mathrm{Be}$ exposure ages of early Pliocene for the Table Mountain plateau and the Sirius Group at Mount Fleming, Dry Valleys, Antarctica. Geology, 23(11), 1007-1010.

Klein, J., R. Middleton, R. Giegengack and P. Sharma. 1988. Revealing histories of exposures using in situ produced ${ }^{26} \mathrm{Al}$ and ${ }^{10} \mathrm{Be}$ in Libyan desert glass. Radiocarbon, 28(2A), 547-555.

Kleman, J. and A. Stroeven. 1997. Preglacial surface remnants and Quaternary glacial regimes in northwestern Sweden. Geomorphology, 19(1), 35-54.

Kubik, P.W., S. Ivy-Ochs, J. Masarik, M. Frank and C. Schlüchter. 1998. ${ }^{10} \mathrm{Be}$ and ${ }^{26} \mathrm{Al}$ production rates deduced from an instantaneous event within the dendro-calibration curve, the landslide of Köfels, Ötz Valley, Austria. Earth Planet. Sci. Lett., $161(1-4), 231-241$.

Kurz, M. D. 1986. Cosmogenic helium in terrestrial igneous rocks. Nature, 320(6061), 434-439.

Lal, D. 1991. Cosmic-ray labeling of erosion surfaces: in situ nuclide production rates and erosion models. Earth Planet. Sci. Lett., 104(2-4), 424-439.

Lal, D. and B. Peters. 1967. Cosmic-ray produced radioactivity on the Earth. In Handbuch der Physik 46. Vol. 2. New York, Springer-Verlag, 551-612.

Lederer, M. C. and V. S. Shirley, eds.. 1978. Table of isotopes. New York, Wiley.

Masarik, J. and R. C. Reedy. 1995. Terrestrial cosmogenic-nuclide production systematics calculated from numerical simulations. Earth Planet. Sci. Lett., 136(3-4), 381-396.
Nishiizumi, K., D. Lal, J. Klein, R. Middleton and J.R. Arnold. 1986. Production of ${ }^{10} \mathrm{Be}$ and ${ }^{26} \mathrm{Al}$ by cosmic rays in terrestrial quartz in situ and implications for erosion rates. Nature, 319(6049), 134-136.

Nishiizumi, K. and 6 others. 1989. Cosmic ray production rates of ${ }^{10} \mathrm{Be}$ and ${ }^{26} \mathrm{Al}$ in quartz from glacially polished rocks. 7. Geophys. Res., $94(\mathrm{~B} 12)$, 17,907-17,915

Nishiizumi, K., C. P. Kohl, J. R. Arnold, J. Klein, D. Fink and R. Middleton. 1991a. Cosmic ray produced ${ }^{10} \mathrm{Be}$ and ${ }^{26} \mathrm{Al}$ in Antarctic rocks: exposure and erosion history. Earth Planet. Sci. Lett., 104, 440-454.

Nishiizumi, K. and 6 others. 1991b. In-situ ${ }^{10} \mathrm{Be}-{ }^{26} \mathrm{Al}$ exposure ages at Meteor Crater, Arizona. Geochim. Cosmochim. Acta, 55(9), 2699-2703.

Nishiizumi, K. and 7 others. 1993. Role of in situ cosmogenic nuclides ${ }^{10} \mathrm{Be}$ and ${ }^{26} \mathrm{Al}$ in the study of diverse geomorphic processes. Earth Surf. Processes Landforms, 18(5), 407-425.

Nishiizumi, K., R. Finkel, J. Klein and C. P. Kohl. 1996. Cosmogenic production of ${ }^{7} \mathrm{Be}$ and ${ }^{10} \mathrm{Be}$ in water targets. 7. Geophys. Res., $101(\mathrm{~B} 10)$, 22,225-22,232.

Norris, T. L., A. J. Gancarz, D. J. Rokop and K.W. Thomas. 1983. Half-life of ${ }^{26}$ Al. F. Geophys. Res., 88, Supplement, Part I, B331-B333.

Phillips, F. M., B. D. Leavy, N. D. Jannik, D. Elmore and P.W. Kubik. 1986. The accumulation of cosmogenic chlorine-36 in rock: a method for surface exposure dating. Science, 231 (4733), 41-43.

Phillips, F. M., M. G. Zreda, S. S. Smith, D. Elmore, P.W. Kubik and P. Sharma. 1990. Cosmogenic chlorine-36 chronology for glacial deposits at Bloody Canyon, eastern Sierra Nevada. Science, 248(4962), 1529-1532.

Phillips, F. M. and 6 others. 1991. Age and geomorphic history of Meteor Crater, Arizona, from cosmogenic ${ }^{36} \mathrm{Cl}$ and ${ }^{14} \mathrm{C}$ in rock varnish. Geochim. Cosmochim. Acta, 55(9), 2695-2698.

Phillips, F. M., M. G. Zreda, L. V. Benson, M. A. Plummer, D. Elmore and P. Sharma. 1996a. Chronology for fluctuations in Late Pleistocene Sierra Nevada glaciers and lakes. Science, 274(5288), 749-751.

Phillips, F. M., M. G. Zreda, M. R. Flinsch, D. Elmore and P. Sharma. 1996b. A reevaluation of cosmogenic ${ }^{36} \mathrm{Cl}$ production rates in terrestrial rocks. Geophys. Res. Lett., 23(9), 949-952.

Phillips, F. M. and 7 others. 1997. Cosmogenic ${ }^{36} \mathrm{Cl}$ and ${ }^{10} \mathrm{Be}$ ages of Quaternary glacial and fluvial deposits of the Wind River Range, Wyoming. Geol. Soc. Am. Bull., 109(11), 1453-1463.

Stone, J. O., G. L. Allan, L. K. Fifield and R. G. Cresswell. 1996a. Cosmogenic chlorine-36 from calcium spallation. Geochim. Cosmochim. Acta, 60(4), 679-692.

Stone, J. O., J. M. Evans, L. K. Fifield, R. G. Cresswell and G. L. Allan. 1996b. Cosmogenic chlorine-36 production rates from calcium and potassium. Radiocarbon, 38(1), 170-171.

Stone, J. O., J. M. Evans, L. K. Fifield, G. L. Allan and R. G. Cresswell. 1998a. Cosmogenic chlorine-36 production in calcite by muons. Geochim. Cosmochim. Acta, 62(3), 433-454.

Stone, J. O., C. K. Ballantyne and L. K. Fifield. 1998b. Exposure dating and validation of periglacial weathering limits, northwest Scotland. Geology, 26(7), 587-590. 